\title{
Sustainable design in the contemporary architecture of tall buildings
}

\author{
Joanna Gil-Mastalerczyk ${ }^{1, a}$ \\ ${ }^{1}$ Kielce University of Technology, Faculty of Civil Engineering and Architecture, Al. Tysiąclecia Państwa Polskiego 7 , 25-314 Kielce, Poland
}

\begin{abstract}
The tall buildings in Singapore - one of the main financial centers of the world - reflect the metropolitan character of the city. These buildings emphasize the importance of the center in the urban landscape. They determine and create a new landscape of the city. Objects, mainly about the function of commercial and prestigious, distinguished by the natural environment-friendly image. Through financial expenditures, they excel in the implementation of innovative solutions in the field ecology. The applied design, facade systems and functional systems are subject to the use of renewable energy sources. Promoting the idea the development of the city "inside". Ecological aspect is the durability of the structure. Modern tall buildings have completely changed the image of the spatial part of the city-state of Singapore and contributed to enhance the individual character and highlight the specifics of the layout and position of the center (combining functions of business, commercial, recreational and residential).
\end{abstract}

\section{Introduction}

The twenty-first century is characterized by significant transformations of civilization, social, economic, political, information and rapid development of any innovative technology. According to the professionals in the field of architecture and urban planning - also century unknown new urbanism from nature, the protection of cultural values, the introduction of new forms of residence into a sustainable housing environment. (...) the era of man-friendly functional and spatial transformations within urban structures (...) different perspective on issues related to the evolution of the city and a variety of new forms of residence to meet all the expectations of man as a result of new current challenges, eg. due to significant climate change, protection of the natural environment (...)[1].

The architecture and the construction are the greatest economic sector in economic aspects and in terms of the flow of raw materials. In the sector of the construction a huge amount of the financial capital is being invested as well as natural. Therefore the role of architecture and the construction in creating the sustainable development is very important.

The assumption of sustainable development should take into account three main priorities with each other in balance: ecology (environmental aspect), economy, society and its culture.

In relation to the architecture - sustainable development - the first time presented in 1998 in GÄVLE and published in Agenda 21 - (document entitled "Sustainable buildings") [2].
The contemporary architecture newest high buildings is the answer and present the result of creative searches, offered modern technology, and sometimes experimental solutions - enabling use on a large scale renewable energy sources.

Designed buildings are not only visually stunning but also built with high performance and sustainable functionality in mind. Innovative building design and responsible construction practices minimize the immediate impact associated with the extraction, manufacturing, and transportation of building materials, and provide the foundation for conservation of natural resources during the years of operation. It is important, to embed sustainable practices in the early stages of design and throughout construction.

The author uses example of modern architecture high buildings in Singapore, presents new trends in the architectural form (sustainable architecture) - in relation to the environment - in harmony with nature and the surrounding landscape.

The modern building construction Singapore completes the network - designed a grand scale - road connections. On a world scale a road infrastructure is singling itself out - bridges and walking-bicycle footbridges. The public transport support 4 metro lines classified in the world to the most automated. Singapore City authorities attach great importance to the development of green areas. Tropical and humid climate favors the vegetation lush vegetation in the many parks that permeate the urban areas. Under the Governmental program, transforming Singapore into a garden city in 2012 created the world famous gardens Gardens by the

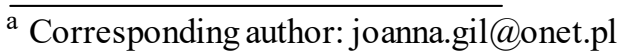


Bay ". It became a place of social integration and the area of highest recreational activities

\section{Sustainable design in the architecture of tall buildings}

The sustainable architecture is one that is carried out in accordance with the principles of sustainable development. The strategy of sustainable development has three dimensions - environmental protection, social inclusion and economic growth.

Sustainable architecture should take into account the whole range of natural and civilization. The process of architectural design should respect the general rules of sustainable design. These include social, cultural and aesthetic. The rules of sustainable design include energy efficiency, renewable energy and the $3 \mathrm{R}$ rule - saving and reuse area, volume, materials, energy, water and waste. It should also be noted that the idea of sustainable development into account aspects related to the architectural design. In particular - is associated with a respect for the place - its natural conditionality and the local building tradition. It is also associated with a respect for the user - including aspects of health, social contacts and a sense of security [3].

Architecture designed buildings should be primarily "a response to the means employed in relation to the challenges of the powerful forces of nature" [4].

These measures should be a component of many factors, including but not limited investor's expectations and vision of the designer. Natural conditions impose different possibilities and solutions bioclimatic. It should also take into account an important humanistic context. The use ecological solutions with local materials is justified by rules of energy efficiency and respect for the place [3].

Generally, it must be found that the next idea of sustainable development is rational and contextsensitive approach to architectural design.

\subsection{Modern solutions - for example Singapore}

City-state Singapore is located in Southeast Asia, near the southern tip of the Malay Peninsula. It is a small island in the Strait of Malacca (an area of about $650 \mathrm{~km}^{2}$ and a coastline of about $138 \mathrm{~km}$ ), surrounded by a team of 56 smaller islands (the area around the archipelago is about $697 \mathrm{~km}^{2}$ ) [5].

A result of work carried out on the acquisition of land from the sea area of Singapore is constantly increasing. The original island was overgrown with vegetation equatorial - due to its location in over $137 \mathrm{~km}$ north of the equator, the climate zone humid, tropical climate and rainforests.

Currently, the city-state Singapore is one of the most developed and richest countries in Southeast Asia and the world $^{\mathrm{a}}$. It is inhabited by over 5 million people. By the

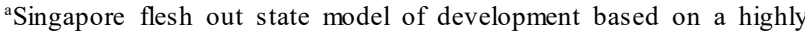
centralized, hierarchical institutions. In the city-state created one of most favorable environments for the development of competitive companies. Specific feature of the model in Singapore has become the realization of selective industrial policy, aimed at promoting strategic sectors of the future, the acquisition of foreign capital, expertise and technology. As a result of increased participation of Singapore in global end of 2019 years is expected to exceed 6.5 million people.

Lack of space has become an investment for the city one of the main barriers to development. A significant part of the investment is localized under the surface deep in the ground.

Like most big cities, life in Singapore takes place partly underground. Under the ground are located metro, multi-level shopping centers and highways.

The new resort set on the coast, in the south-eastern part of Singapore, was a complex of luxury high building. It combines the features of business, commercial, recreational and residential buildings. It is now one of the largest financial centers, commercial and banking world.

The complex newest buildings of the city is made up of high buildings and multi-storey buildings, towers commercial, service, residential and underground parking. The towers are equipped with numerous green vertical gardens. In addition to high usability, they represent about ecological character of this part of the city.

\subsubsection{CapitaGreen, Singapore, designer Toyo Ito \& Associates (Figure 1-4)}

"This office tower presents fresh opportunities to develop a city centre which is at the cutting edge of sustainable design. It is a green building both physically and environmentally (...)" - Mr Tan ChuanJin - Minister of State for National Development and Manpower [8]

CapitaGreen is an iconic landmark on the skyline of Singapore with its striking sculptural petalled funnel on the crown of the building and its impressive façade of greenery. Standing tall at 245 metres, building offers approximately 702,000 square feet of premium Grade A office space - level 3 to 36 .

The development will feature specially commissioned art installations by internationally acclaimed artists on level 1 and exceptional facilities such as an exclusive club on level 38, and a sky forest and restaurant on level 40. Located in the heart of Singapore's Central Business District, CapitaGreen have close access to the station Raffles Place and Telok Ayer MRT stations [9].

CapitaGreen is an ecological building with its environmentally-friendly features and a green 'living' façade (Figure 1-2).

With the inclusion of numerous state-of-the-art energy-saving features, the completed office tower is designed to achieve the Green Mark Platinum award, the highest accolade in recognising environmentallyfriendly buildings from the Building \& Construction Authority of Singapore [10].

trade, especially exports of services, goods, high technology and rapid economic growth.

In addition, improving efficiency and stimulating innovation translates simultaneously increasing the attractiveness of a location for foreign direct investment in the area of high technology. These changes additionally enhance national long-term competitiveness by increasing the attractiveness of the location for inflows of high-tech foreign direct investment [6] 


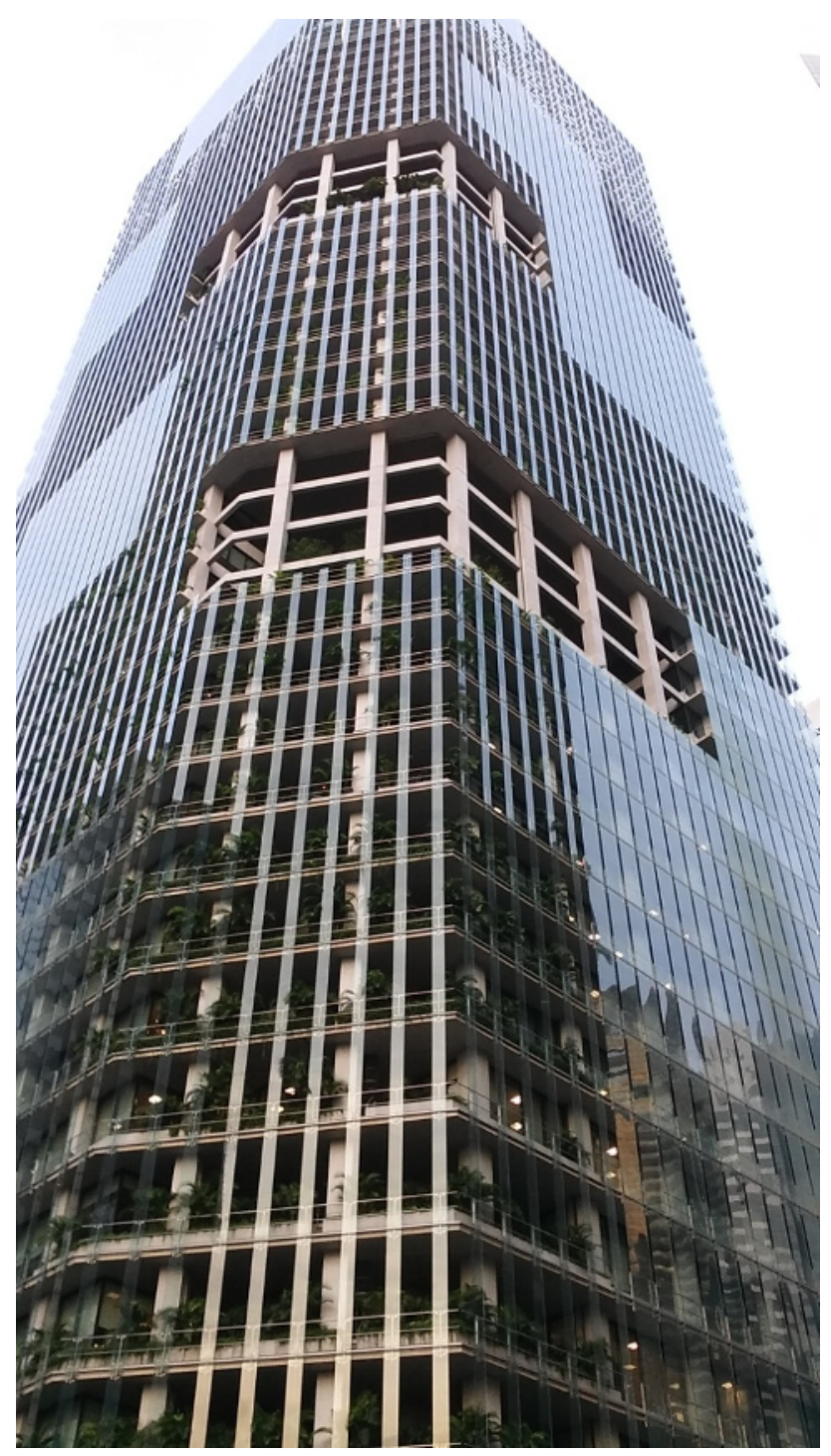

Figure 1. CapitaGreen (2012-2014), Architect Toyo Ito \& Associates Architects. Innovatively shaped architecture of the buildings with the introduction of greenery and trees in the entire layout, Singapur (photo by autor, 2016).
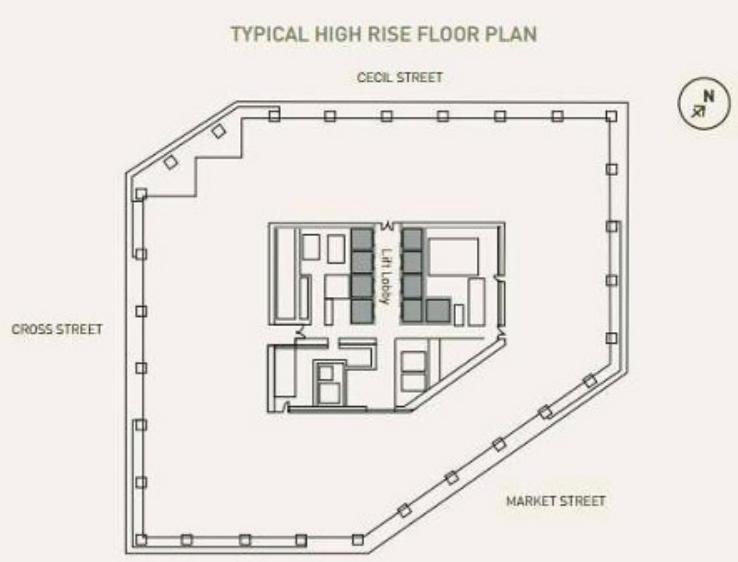

Figure 3. CapitaGreen (2012-2014), Architect Toyo Ito \& Associates Architects. Typical high rise floor plan (source: [9]).

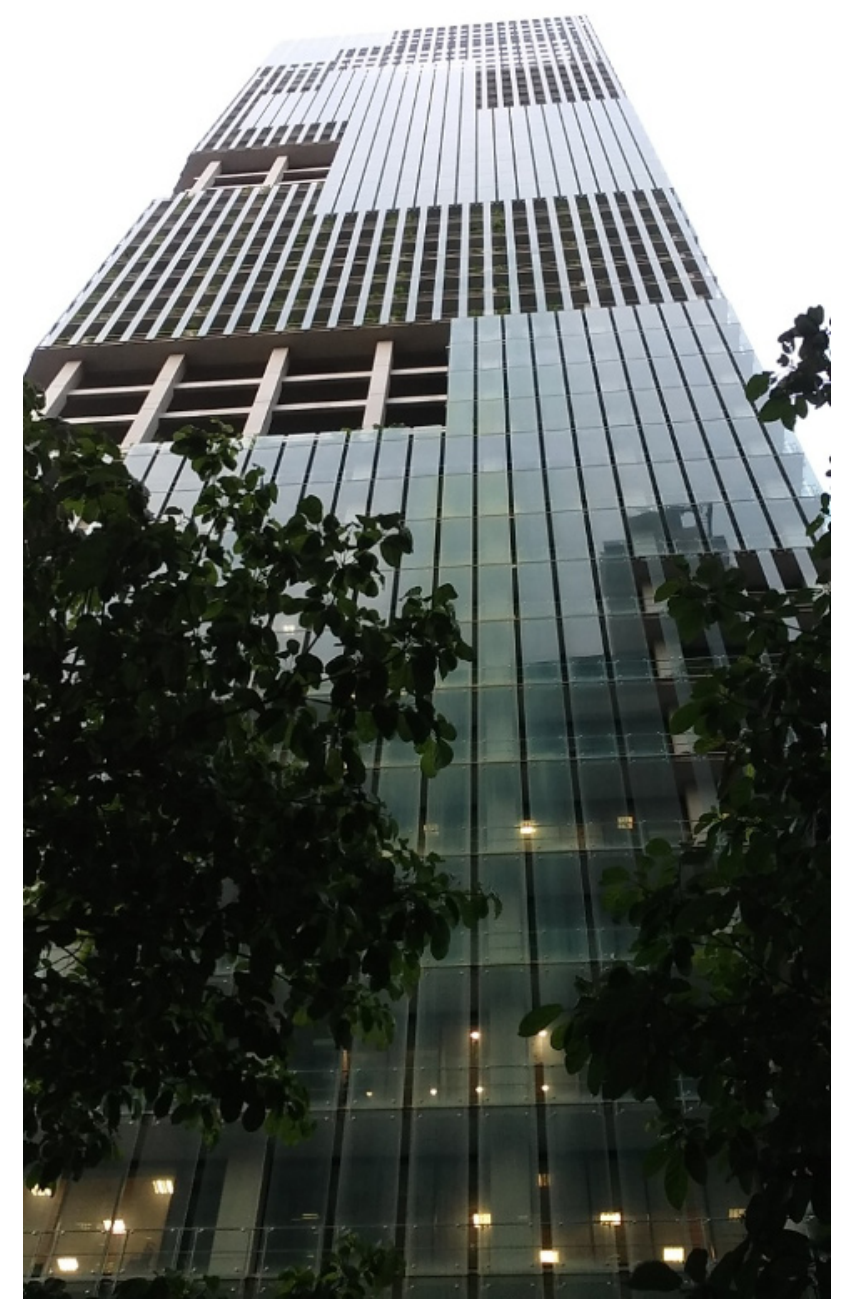

Figure 2. CapitaGreen (2012-2014), Architect Toyo Ito \& Associates Architects. Innovatively shaped architecture of the buildings with the introduction of greenery and trees in the entire layout, Singapur (photo by autor, 2016).

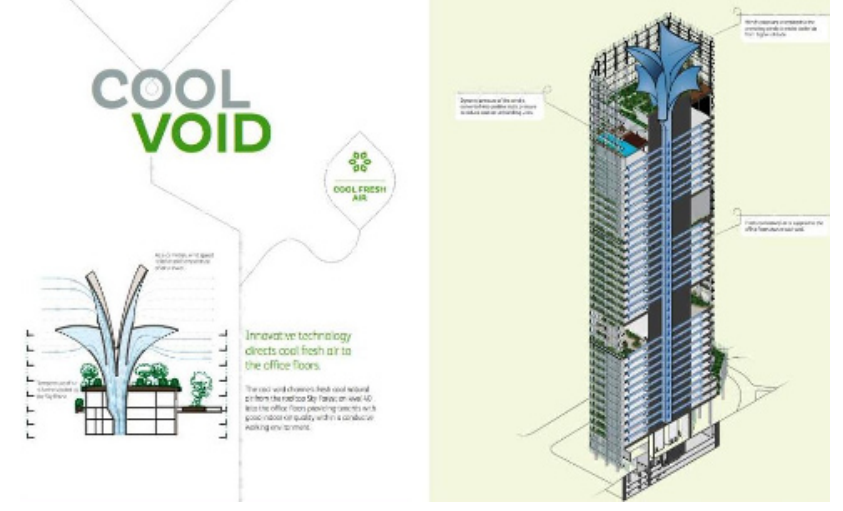

Figure 4. CapitaGreen (2012-2014), Architect Toyo Ito \& Associates Architects. Scheme air flow throughout the building, effectively regulating the building's temperature (source : [8]).

This is articulated through the use of extensive sky gardens on three levels and Sky Forest on the roof, which 
forms part of a unique air circulatory system that Arup designed [10] (Figure 4).

Installed with a wind scoop, the air circulatory system, much like that of a living plant's, draws cool air from the sky forest where tropical trees are planted. The air is then delivered through the 'Inner Tube', an empty central core, to each floor. Overall energy consumption is significantly lowered as a result [10].

A cool void at the centre core of the property permits air flow throughout the building, effectively regulating the building's temperature [8].

CapitaGreen houses a large expanse of greenery. Apart from the sky forest on level 40, there are also sky terraces on levels 5, 14 and 26, and greenery on every floor, allowing tenants greater proximity to and intimacy with nature [9].

To irrigate the building's plants, it will harness innovative water-saving techniques such as rainwater harvesting.[8]

Air-conditioning for the office floors is provided via innovative technology which takes in fresh cool natural air from the crown of CapitaGreen at lower energy consumption, providing tenants with better indoor air quality [9] (Figure 4).

Each floor features generous $3.2 \mathrm{~m}$ floor-to-ceiling heights to provide uninterrupted views of Marina Bay and the rest of the CBD. A double glazed facade system reduces solar heat gain, while an accompanying green façade behind it is designed to lower surface temperature, diffuse sunlight and provide beautiful dappled natural light into the building. The result is a well-lit and cool indoor environment that tenants and visitors can be in [10].

In meeting CapitaGreen's high design standards, Arup's team of vertical transport specialists designed a premium grade, energy-efficient lift service that integrates a strategic selection of destination control service and regenerative drive technologies. These greatly benefit the building's crowd management as tenants and visitors are brought to their destinations in the most time and energy-efficient way possible [10].

\subsubsection{Marina Bay Sands, Singapore, designer Moshe Safdie (Figure 5-7)}

"Marina Bay Sands is really more than a building project, it is a microcosm of a city rooted in Singapore's culture, climate, and contemporary life" - architect Moshe Safdie [11].

The complex of commercial and prestigious tall buildings is located at the "Marina Bay Sands". The building complex is characterized by an innovative functional and spatial large urban complex. An individually shaped architecture (with vertical layout) distinguishes the each on.

The object Marina Bay Sands was designed by worldrenowned architect - Moshe Safdie for the Las Vegas Sands Corporation (cooperation: James Carpenter, Antony Gormley, Ned Kahn Sol Lewitt and Chongbin
Zheng). Building has 929.000 square meter (10 million square-foot) $)^{b}[11]$.

The building Marina Bay Sands was designed in a way that uses the principles of sustainable development. The objective of sustainable development has become the growth prosperity and the harmonious arrangement of the relationship between man and nature (Figure 5-7).

In the architecture are used a different system energy efficiency of the building. The environmental impact of building operation lifetime is much higher than the construction industry. Implementation of responsible operating practices reduces the consumption of natural resources and as a result improves the comfort of the guests and team members.

It is important to embed sustainable practices in the early stages of design and throughout construction.

During the construction and renovation the unique design features of the environment, the optimization of mechanical systems, select sustainable materials and recycling construction waste were used.

Building Marina Bay Sands was designed to introduce abundant natural daylight to illuminate indoor areas, reducing the need for additional lighting. Specially designed convex and concave roofs reduce heat gain into the podium interior. Sun shading across the glass façade in the form of balconies, vertical fins, and canopies were installed as well [12].

The basis for action has become a quest for continuous improvement, regularly examine and test new products to stay at the cutting edge of technological innovation in the industry.

In the building regenerative drives on elevators, which require $40 \%$ less energy than comparable nonregenerative elevators were used.

\footnotetext{
${ }^{\mathrm{b}}$ This new urban place integrates the waterfront promenade, a 74,000 square meter (800,000 square-foot) multi-level retail arcade, and the iconic Museum of ArtScience on the promontory. Located along the network of public paths are also two theaters with a combined 4,000 seats, a casino, a 9,000 square meter (96,000 square-foot) convention and exhibition center, and a hydraulically adjustable public event piazza of 5,000 square meters (54,000 square feet). Combining indoor and outdoor spaces and providing a platform for a wide array of activities, this vibrant, 21 st-century cardo maximus, or grand arcade, also connects to the subway and other transportation. A series of layered gardens provide ample green space throughout Marina Bay Sands, extending the tropical garden landscape from Marina City Park towards the Bayfront. The landscape network reinforces urban connections with the resort's surroundings and every level of the district has green space that is accessible to the public. Generous pedestrian streets open to tropical plantings and water views. Half of the roofs of the hotel, convention center, shopping mall, and casino complex are planted with trees and gardens. Three 55-storey hotel towers anchor the district and are connected at the top by the 1 hectare (2.5-acre) SkyPark. An engineering marvel 200 meters (656 feet) above the sea, the SkyPark spans from tower to tower and cantilevers 65 meters (213 feet) beyond. It accommodates a public observatory, gardens, a 151 meter-long (495 foot-long) swimming pool, restaurants, and jogging paths and offers sweeping panoramic views, a formidable resource in a dense city like Singapore. Shielded from the winds and lavishly planted with hundreds of trees, the SkyPark celebrates the notion of the Garden City that has been the underpinning of Singapore's urban design strategy [11].
} 


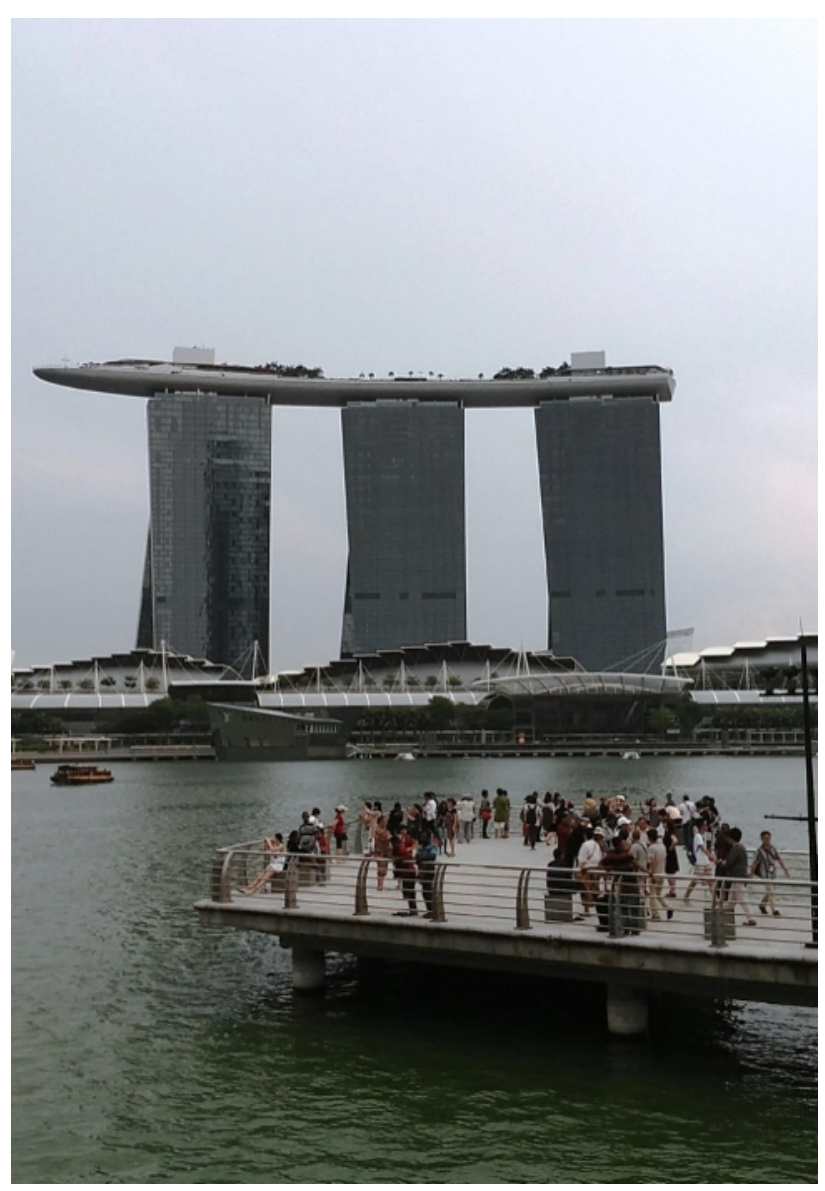

Figure 5. Marina Bay Sands (2009-2011), architect Moshe Safdie (photo by autor, 2016).

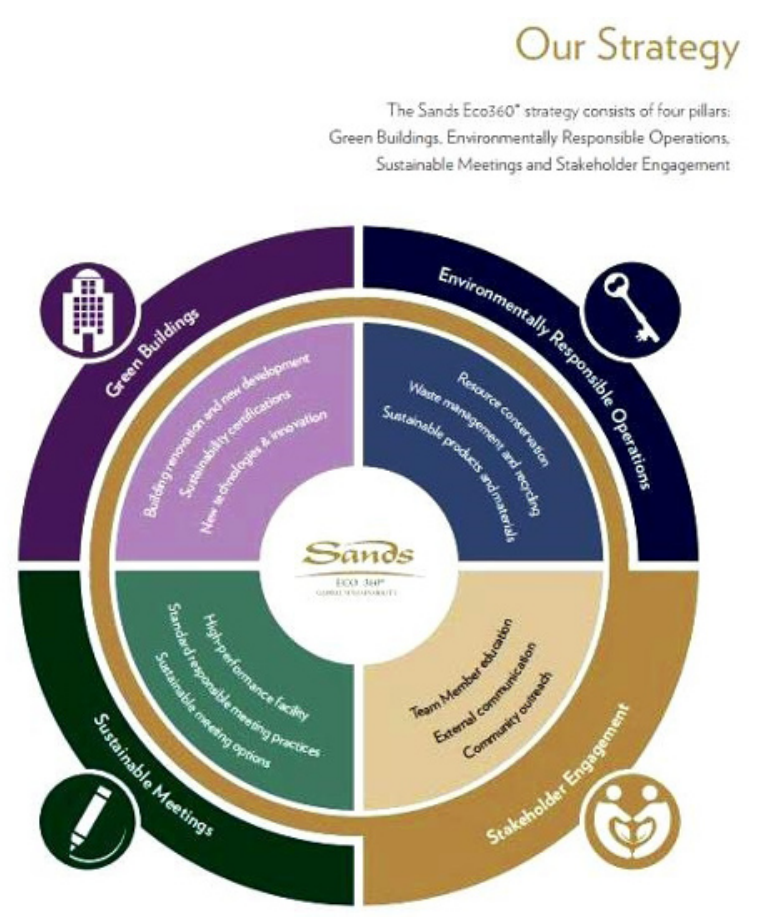

Figure 6. Scheme strategy (Marina Bay Sands). The Sands Eco360 $0^{\circ}$ strategy consists of four pillars: Green Buildings, Environmentally Responsible Operations, Sustainable Meetings and Stakeholder Engagement (source: [13]).

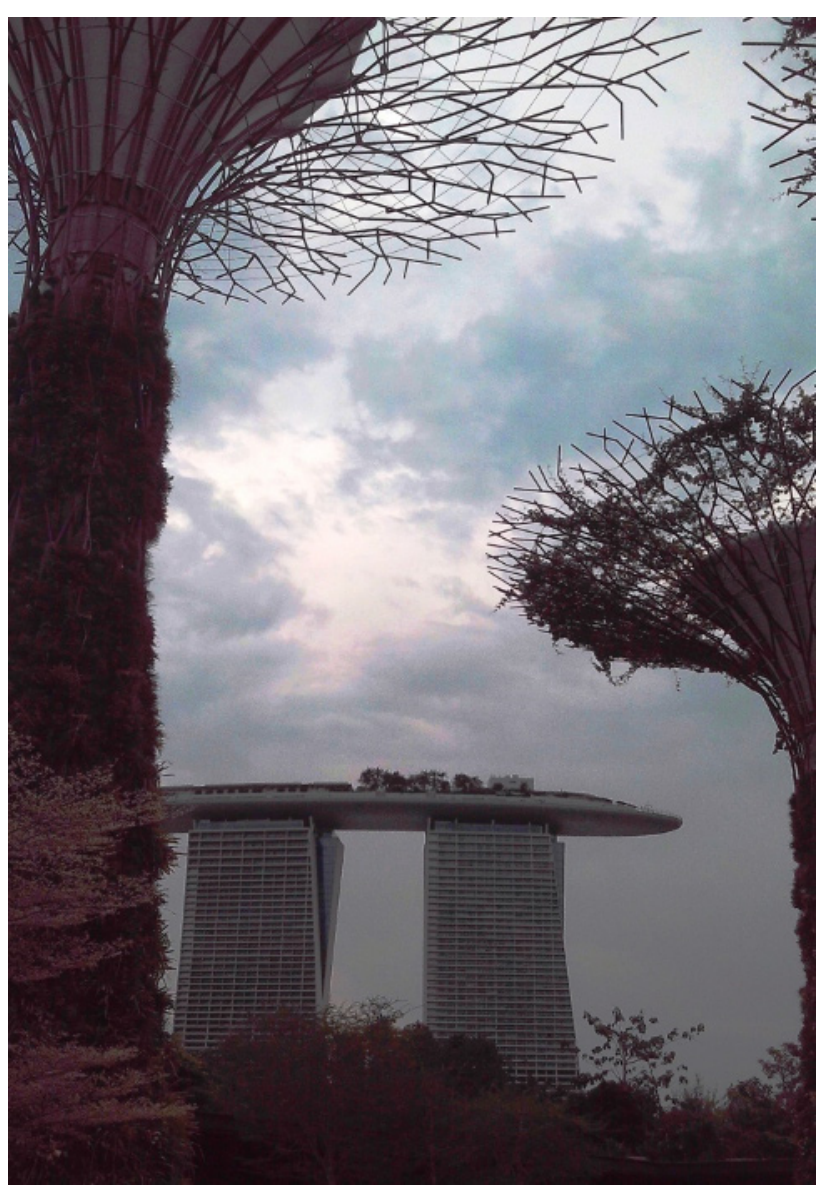

Figure 7. Marina Bay Sands (2009-2011), architect Moshe Safdie, the view from the 'Gardens by the Bay' (photo by autor, 2016).

The escalators at the mall retail and convention center are designed to stop when it is not in use and start when it detects incoming people [12]

In addition energy, water and resource conservation projects, is an extensive waste management strategy, including food waste diversion, to help to improve waste reduction, diversion and total environmental impact. In convention centre there are over 250 rooms. A special air conditioning system works in a building - air conditioning is turned on only during meetings [12].

Global sustainability programme, Sands ECO360 is the ethos that guides the company in responsible operations, reducing our carbon footprint and overall environmental impact. Sands $\mathrm{ECO} 360^{\circ}$ integrates the company's best practices, technologies and methodologies in the area of sustainability across all properties. It consists of four priorities: Green Building, Environmentally Responsible Operations, Green Meetings and Sustainability Education and Outreach [12] (Figure 6).

The building is constructed with high performance and sustainable functionality in mind. Innovative building design and responsible construction practices minimize the immediate impact associated with the extraction, manufacturing, and transportation of building materials, and provide the foundation for conservation of natural resources during the years of operation [12].

The attractive location allows to make custom solutions functional and spatial and urban infrastructure. 
In spite of dense and steadily expanding development (Marina Bay Sands Singapore), development of the area are interesting and attractive solutions. There are places for rest and recreation equipment. There are walking paths, communication a coastal, marina, cycle routes, waterways.

Intensive building Marina Bay Sands contrasts with the lush by greenery squares, parks, botanical gardens. Located near the 'Marina Boulevard' world-famous gardens 'Gardens by the Bay' are the site of frequent cycling and walking. Above the gardens dominates the Singaporean group super-trees (Figure 7). These are extraordinary, multi-functional structures - referring to a form of real trees. Their height is 25 to $50 \mathrm{~m}$. Super trees are vertical space breeding many species of plants. It provide communities the visiting shadow in their environment and are a kind of environmental engines, producing electricity (photovoltaic). Also collect rain water (irrigation system and fountains) and are part of the cooling systems.

The whole assumption is distinguished by appropriate shaping of composite architecture. The developed spatial concept, high-density building, was located over the water. The area is a kind a edge of the city and in contact with water - rich natural area and the coast.

The convenient location allows to make custom solutions functional and spatial and urban infrastructure. Despite the dense and steadily expanding development, development of the area are interesting and attractive solutions.

Intensive building contrasts with the lush greenery of numerous squares, parks, botanical gardens. Located near the 'Marina Boulevard' gardens 'Gardens by the Bay' area of over 100 ha are the site of frequent cycling and walking.

A method of forming architecture addressing a client's needs, their lifestyle and climatic conditions. Style features surround of the buildings correspond to the priorities of sunshine, in terms of the location of the mutual, proper shading and ensure high environmental values of work and life.

All objects distinguishes the natural environmentfriendly image. Through a considerable financial effort, excel in the implementation of innovative solutions in the field of ecology. Applied design, facade systems and functional systems are subject to the use of renewable energy sources. Promoting the idea of development of the city "inside". It reduce the absorption of natural areas. Ecological aspect is the durability of the structure.

Forms of skyscrapers (with different bases) form polyhedra arranged next to one another. Standing close together, are a group of towers emphasizing reach metropolitan area - the coastal part of the city. Dynamic and light forms - on the shoulders tapering - form the structure of a vertical city. It is possible here to find the idea of the sustainable development. Contemporary tall buildings have completely changed the image of surround this part of town. Contributed to enhance the individual character and highlight the specific nature of the facility and its location. Emphasize the importance of the center in the urban landscape and define and create a new landscape of the city.

\section{Conclusions}

The overall conclusion is that sustainable, energyefficient architecture of modern tall buildings must be reasonable. Climatic factors and increasing requirements for energy efficiency in buildings will be determined by formal solutions and functional space.

Presented solutions design tall buildings are characterized by innovative and experimental development of buildings and urban social space in relation to nature. The natural landscape, the assumptions on water and recreation areas.

Original architectural forms are distinguished by extraordinary visual effects and aesthetic in symbiosis with nature and landscape. This is characterized by the search for new ideas and visions to shape the environment to live and work.

The search for new forms of architectural related to the environment. As a result, design solutions in innovative shaped vertical structure of urban development (commercial and prestigious), will contribute to improvement of the work environment, house a living environment and the quality of architectural space.

Generally it should be noted that the presented solution is an example of sustainable design in the architectural and urban planning and architectural scales. Urban context has played a significant role in shaping the architectural because "there is no architecture without urban planning and urban design without the architecture".

Design and realization of architecture objects promotes the idea of "saving the city." The aspect "savings" in the consumption of energy, water, natural resources, reduce waste, and preference for green transport.

In summary that contemporary architecture and sustainable building (for example, tall buildings of Singapore):

- create a safe and healthy environment to live and work,

- does not pollute the environment,

- generates low maintenance,

- gives users the satisfaction staying in it and a pleasure to contact passers and the public,

- the modern building represents a technical level corresponding to the needs of society and civilization, reflects the social and cultural aspirations of society, - responds to the needs of the market supply and demand.

This is confirmed by numerous research programs (created in the nineties the twentieth century.), Focusing on issues of sustainable development. Their objective is to test systems for assessing and improving the quality of buildings in terms of environmental impact (These are e.g.: LEED (Leadership in Energy and Environmental Design, USA), GBC (Green Building Challenge, Europe, Japan, Canada, USA), BREEAM (Building Research Establishment Environmental Assessment Method, United Kingdom, BEPAC (Building Environmental Performance Assessment Criteria, Canada)). 
Sustainable architecture designed and implemented in accordance with the standards of sustainable development has a positive impact on the environment helping to reduce consumption of natural resources and reduce environmental degradation (environmental benefits). Sustainable architecture has a beneficial effect on the health and safety of users - contributes to improving the comfort, health and safety of users. It contributes to improve the quality of life (social benefits). It has an impact on increasing the earned benefits and profits (economic benefits).

\section{References}

1. W. Seruga, Nowe formy zamieszkania $w$ zrównoważonym środowisku mieszkaniowym/ New forms of residence in a sustainable housing environment [w:] Środowisko mieszkaniowe/ Housing Environment, W. Seruga (red.), 12/2013, pp. 114-133 (Wyd. Politechnika Krakowska, Kraków, 2013).

2. Agenda 21 on Sustainable Construction, CIB Report Publication 237 - ISBN 90-6363-015-8, Rotterdam.

3. B. Ostrowska, Zrównoważony dom jutra a lokalna tradycja/Tomorrow's Sustainable House and Local Tradition [w:] Środowisko mieszkaniowe/ Housing Environment, W. Seruga (red.), 12/2013, pp. 34-41 (Wyd. Politechnika Krakowska, Kraków, 2013).

4. A. Cząstka, Architektura a natura. Problem mimesis $w$ architekturze, p. 163 (Wyd. Politechnika Krakowska, Kraków, 2007).

5. K. Kubiak, Twierdza, której nie było (Wyd. Książka i Wiedza, 2010).

6. M. Żmuda, Źródła przewagi konkurencyjnej matej gospodarki otwartej w dobie powiazań globalnych Singapur w latach 2007-2012/ Sources of Competitive Advantage of a Small Open Economy in the Era of Global Interconnections - Singapore in the Years 2007-2012, Zeszyty Naukowe Uniwersytet Ekonomiczny w Krakowie, 9(945), pp. 60-72 (Kraków, 2015).

7. W. Seruga, Jedność architektury z otoczeniem/ The Unity of Architecture and its Surroundings, Czasopismo Techniczne Architektura/ Technical transactions Architecture, 3-A/2011, Z. 12, rok 108, Issue 12, Year 107, p. 133-145 (Wyd. Politechnika Krakowska, Kraków, 2011).

8. http://capitagreensingapore.com, (July 2016).

9. http://www.cct.com.sg/system/misc/Portfolio_Capita Green.pdf, (July 2016).

10. http://www.arup.com/projects/capitagreen (July 2016).

11. http://www.msafdie.com/file/1698 (July 2016).

12. https://www.marinabaysands.com (July 2016).

13. http://www.marinabaysands.com/content/dam/singap ore/marinabaysands/master/main/home/companyinformation/environmental-sustainability/eco_mbsgreen-facts.pdf, (July 2016). 